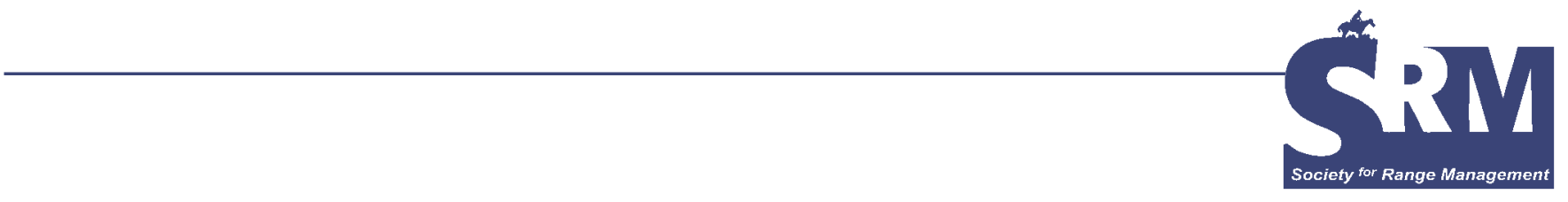

\title{
Grassland Degradation and Our Strategies: A Case from Shanxi Province, China
}

\section{By Zhang Jin-Tun}

\section{Introduction}

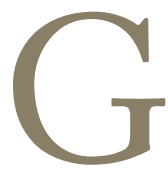

rasslands cover $41 \%$ of the earth's land surface and provide livelihoods for nearly 800 million

r people. Additionally, grasslands provide forage for livestock, wildlife habitat, carbon and water storage, renewable energy, recreation, and tourism. Grasslands also remain the primary source of genetic material for improving our food crops and for an increasing number of pharmaceuticals. ${ }^{1,2}$ The health of the world's grasslands is declining largely due to human-induced modifications, such as agriculture, overgrazing, excessive use of fire, fragmentation of areas, and urbanization. ${ }^{3}$ A recent study by the World Resources Institute to gauge the impact of human activity on grasslands found that a major reduction in the extent of grasslands has occurred in many areas. ${ }^{4}$ For example, only $9.4 \%$ of North America is now covered by grasslands, and only $20 \%$ of Latin America. ${ }^{4}$ Because of their contribution to human welfare, management of grasslands has become a more important part of environmental management worldwide. ${ }^{5,6}$ Most research has focused on productivity, biodiversity, and the effects of grazing. Our understanding of grassland degradation includes its causes, mechanisms, restoration, and management but is not sufficient, particularly for grasslands in China. ${ }^{7-10}$

In China, grasslands cover more than $40 \%$ of the total land area, with $84 \%$ of that being located in western China. ${ }^{11-13}$ Grassland is the largest terrestrial ecosystem of China, much of it semiarid and high plateau pastoral land. Grassland is the base of national animal husbandry, and is closely related to the food production of China. However, China's grasslands are being subjected to many negative forces and rapid change. According to Miller, estimates sug- gest that about $34 \%$ of all rangelands in China are moderately to severely degraded and about $90 \%$ are degraded to some degree. ${ }^{14}$ Therefore, the management of grassland in China is extremely significant. This paper analyzes the present state of grassland degradation and its management strategies for the future, using Shanxi Province as an example.

\section{Definition of Grassland Degradation}

Grassland degradation can be defined as a kind of desertification. The desertification can be defined as land degradation in arid, semiarid, or dry areas because of climate change and human activities. The results of desertification are the reduction of biological and economic productivity or the decrease of biodiversity for cropland, grassland, and woodland, including the loss of soil substance, change of soil structure, and disappearance of natural vegetation. ${ }^{15}$ In fact, grassland degradation is a retrogressive succession of grassland vegetation. ${ }^{2,13}$

\section{Problems of Grassland Management}

Grassland degradation has gradually increased in severity since the 1970s in China. The area of natural grassland is gradually shrinking and the quality is degrading. The capacity of grassland to feed animals is decreasing and most of the grasslands are being overgrazed. The productivity and biodiversity of grasslands are gradually decreasing, as is environment quality, which seriously threatens the sustainable development of China. Currently, 90\% of the grassland is being degraded to varying extents, 2,13,16 among which the area of the grassland with serious degradation accounts for more than half of the total. The area of seriously degraded grassland has reached 185 million ha, and is increasing at an annual rate of 2 million ha. ${ }^{7,17}$ 
Table 1. Ecological types of grasslands and their characteristics in Shanxi Plateau

\begin{tabular}{|c|c|c|c|c|c|c|c|c|}
\hline No. & $\begin{array}{l}\text { Grass- } \\
\text { land } \\
\text { types }\end{array}$ & $\begin{array}{c}\text { Areas } \\
\left(10^{4} \text { ha }\right)\end{array}$ & $\begin{array}{c}\% \text { of the } \\
\text { total grass- } \\
\text { lands }\end{array}$ & $\begin{array}{l}\text { Distribution } \\
\text { and } \\
\text { characteris- } \\
\text { tics }\end{array}$ & $\begin{array}{c}\text { Eleva- } \\
\text { tion } \\
\text { (m) }\end{array}$ & $\begin{array}{c}\text { Produc- } \\
\text { tivity } \\
\text { (t/ha) }\end{array}$ & $\begin{array}{l}\text { Keeping } \\
\text { live- } \\
\text { stock } \\
\text { (sheep/ } \\
\text { ha) }\end{array}$ & Main species \\
\hline 1 & $\begin{array}{l}\text { Temperate } \\
\text { steppe } \\
\text { grassland }\end{array}$ & 44.0 & 11.69 & $\begin{array}{l}\text { low mountain } \\
\text { and hills in north } \\
\text { and northeast } \\
\text { Shanxi; chestnut } \\
\text { and loess soil }\end{array}$ & $<1,500$ & 3.10 & 270 & $\begin{array}{l}\text { Stipa bungeana, Thymus } \\
\text { serpyllum, Cleistogenes } \\
\text { chinensis, Cleistogenes } \\
\text { squarrosa, Astragalus } \\
\text { scaberrimus, Polxgala } \\
\text { tenuifolia, Artemisia vesti- } \\
\text { ta, Lespedeza davurica, } \\
\text { Agropyron cristatum, } \\
\text { Gueldenstaedtia multifiora }\end{array}$ \\
\hline 2 & $\begin{array}{l}\text { Temperate } \\
\text { scrub- } \\
\text { grassland }\end{array}$ & 140.1 & 37.22 & $\begin{array}{l}\text { low hills in south } \\
\text { Taihang, Luliang } \\
\text { Mountains, } \\
\text { Qinxian, Qinyuan, } \\
\text { Zuoquan } \\
\text { Mountains; cin- } \\
\text { namon soil with } \\
\text { bare rocks }\end{array}$ & $\begin{array}{l}800- \\
1,700\end{array}$ & 4.21 & 150 & $\begin{array}{l}\text { Bothriochloa ischaemum, } \\
\text { Themeda triandra var. } \\
\text { japonica, Vitex negundo } \\
\text { var. heterophylla, } \\
\text { Hippophae rhamnoides, } \\
\text { Poa annua, Zizyphus juju- } \\
\text { ba var. spinosa, } \\
\text { Heteropappus altaicus, } \\
\text { Roegneria kamojiohwi }\end{array}$ \\
\hline 3 & $\begin{array}{l}\text { Temperate } \\
\text { grassland }\end{array}$ & 60.51 & 16.08 & $\begin{array}{l}\text { wide area south } \\
\text { of Hengshan } \\
\text { Mountains; cin- } \\
\text { namon and } \\
\text { mountain cinna- } \\
\text { mon soils }\end{array}$ & $\begin{array}{l}1,300- \\
2,000\end{array}$ & 5.0 & 190 & $\begin{array}{l}\text { Bothriochloa ischaemum, } \\
\text { Arundinekka hirta, } \\
\text { Artemisia spp., Pao spp., } \\
\text { Carex lanceolata, } \\
\text { Themeda triandra var. } \\
\text { japonica, Heteropappus } \\
\text { altaicus, Elymus dahuri- } \\
\text { cus, Festuca sp. }\end{array}$ \\
\hline 4 & $\begin{array}{l}\text { Temperate } \\
\text { bush land }\end{array}$ & 80.00 & 21.26 & $\begin{array}{l}\text { Luya Mountains, } \\
\text { Guandi } \\
\text { Mountains, } \\
\text { Guanqin } \\
\text { Mountains; } \\
\text { mountain cinna- } \\
\text { mon and mead- } \\
\text { ow soils }\end{array}$ & $\begin{array}{l}1,400- \\
2,000\end{array}$ & 4.70 & 180 & $\begin{array}{l}\text { Hippophae rhamnoides, } \\
\text { Rosa xanthina, Lepedeza } \\
\text { bicolor, Ostryopsis davidi- } \\
\text { ana, Rosa xanthina, } \\
\text { Spiraea pubescens, } \\
\text { Artemisia spp., Carex } \\
\text { spp., Potentilla chineen- } \\
\text { sis, Medicago falcata }\end{array}$ \\
\hline 5 & $\begin{array}{l}\text { Mountain } \\
\text { meadow }\end{array}$ & 37.00 & 9.83 & $\begin{array}{l}\text { cold area above } \\
\text { forest line in } \\
\text { Taiyue, Taihang, } \\
\text { Luliang, Wutai, } \\
\text { Hengshan and } \\
\text { Zhongtiao moun- } \\
\text { tains; meadow soil }\end{array}$ & $>2,000$ & 6.90 & 75 & $\begin{array}{l}\text { Carex spp., Cobresya bel- } \\
\text { lardii, Avena fatua, } \\
\text { Oxytropis coerul, Festuca } \\
\text { ovina, Sanguisorba offici- } \\
\text { nalis, Polygonum viviparum, } \\
\text { Cleistogenes spuarrosa }\end{array}$ \\
\hline 6 & $\begin{array}{l}\text { Temperate } \\
\text { "Savannah" } \\
\text { grassland }\end{array}$ & 11.44 & 3.03 & $\begin{array}{l}\text { forest edge and } \\
\text { tree windows } \\
\text { area in all moun- } \\
\text { tains; mountain } \\
\text { cinnamon soil }\end{array}$ & $\begin{array}{l}1,700- \\
2,400\end{array}$ & 4.37 & 120 & $\begin{array}{l}\text { Deyeuxia arundinacea, } \\
\text { Spodiopogon sibiricus, } \\
\text { Vicia unijuga, Bromus } \\
\text { inermis, Setaria viridis, } \\
\text { Medicago falcate, Vicia } \\
\text { amoena }\end{array}$ \\
\hline 7 & $\begin{array}{l}\text { Wet } \\
\text { meadow }\end{array}$ & 3.34 & 0.89 & $\begin{array}{l}\text { wet land along } \\
\text { rivers, around } \\
\text { water reserve } \\
\text { and lakes; wet } \\
\text { meadow soil }\end{array}$ & $\begin{array}{c}240- \\
800\end{array}$ & 3.90 & 105 & $\begin{array}{l}\text { Calamagrostis } \\
\text { pseudophragmites, } \\
\text { Phragmites communis, } \\
\text { Tamarix chinensis, } \\
\text { Pennisetum } \\
\text { alopecuroides, Salsola } \\
\text { collina, Carex spp. } \\
\text { Ranunculus tanguticus }\end{array}$ \\
\hline
\end{tabular}




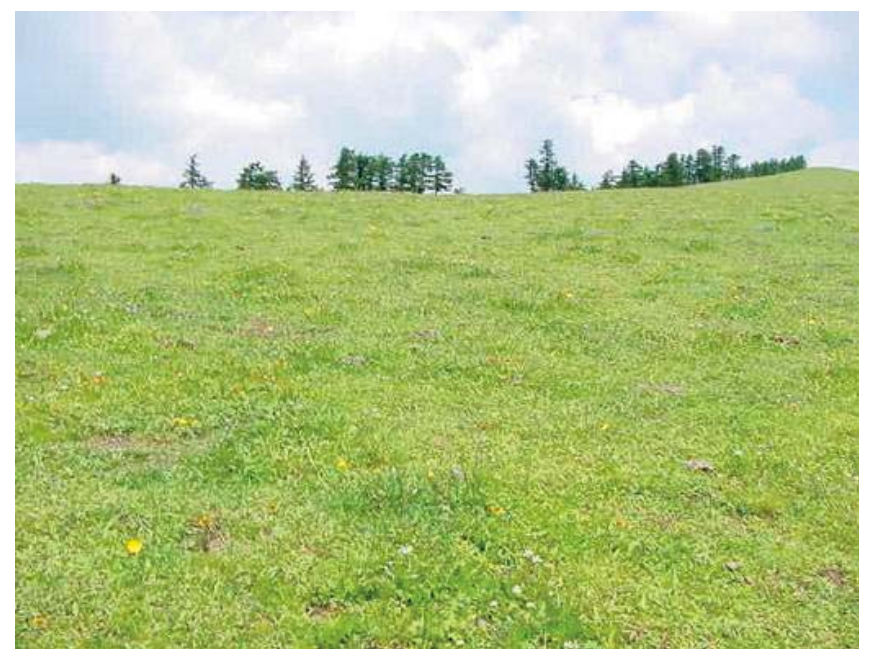

Photo 1. Moderately degraded mountain meadow grassland in Luya Mountains, Shanxi.

Grassland degradation is the main challenge facing grassland managers in the new century for China. To establish sustainable grassland farming in China, we have to study the cause, classification, restoration, and control strategies of grassland degradation. Here we use Shanxi Province as a case to study these problems.

Shanxi Province, a part of loess plateau, is located at $\mathrm{N} 34^{\circ} 35^{\prime}-\mathrm{N} 40^{\circ} 43^{\prime}, \mathrm{E} 110^{\circ} 15^{\prime}-\mathrm{E} 114^{\circ} 33^{\prime}$, and is a mountainous province in China rich in natural grassland resources. There are 3.76 million ha of natural grasslands. However, large areas of grasslands were degraded in the past few decades because of overutilization and worsening natural conditions. Over $80 \%$ of the total land area is mountainous, and most lands are over 1,000 m. The highest mountain in Shanxi is Beitai, the main peak of the Wutai Mountains with an elevation of 3,058 $\mathrm{m}$, and the lowest land, with an elevation of $245 \mathrm{~m}$, lies in Yuanqui County in the south of Shanxi. The area has a continental climate, being warm and rainy in summer, cold and dry in winter. The annual mean temperature varies from $8^{\circ} \mathrm{C}$ in the north to $12^{\circ} \mathrm{C}$ in the south; the mean precipitation varies from $350 \mathrm{~mm}$ to $570 \mathrm{~mm}$. Based on the system of national vegetation regionalization, 2 vegetation regions are recognized in this province: ${ }^{17}$ a temperate steppe region distributed in the north, and a warm temperate deciduous broad-leaved forest region in the south. The boundary of these 2 vegetation regions is the Hengshan Mountain range. Correspondingly, 2 soil regions, the chestnut soil region and cinnamon soil region, can be identified. ${ }^{18}$

\section{The Causes of Grassland Degradation}

There are various factors causing grassland degradation, such as long-term drought, wind and water erosion, dust storms, plagues of rats and insects, and other natural factors as well as excessive grazing, heavy mowing, transferring grassland to farmland, digging medicinal plants, mining, and other human economic activities. ${ }^{819-20}$ The interactions of these factors can speed up grassland degeneration; for instance, wind erosion of soil can lead to loss of soil water and to desertification, which could cause plagues of rats and insects. ${ }^{2,8}$ In the literature, different authors emphasize different factors. ${ }^{21,22}$ The grasslands have been used for a long time by human beings in northern China, but their serious degradation started only 40 years ago when population increased quickly, which implies that human activities are the main factors affecting grassland degradation. ${ }^{8,23}$

Almost all grasslands in Shanxi plateau are in a degrading condition. ${ }^{2}$ Human activities are the principal factors affecting this procedure. Many grasslands in mountainous areas below 1,200 $\mathrm{m}$ have been reclaimed into cropland. It is difficult to find a continuous grassland in this region due to such reclaiming. The water and soil loss becomes serious and soil quality becomes low after reclaiming. The local farmers do not invest in the land by using grassland-cropland rotation farming systems; rather, they continuously grow crops, which destroys the land. ${ }^{2}$

Digging medicinal plants, collecting fire-grass, and felling firewood in a grassland can cause its degradation. There are many medicinal plants in Shanxi, including licorice, Huangqi, mahuang, and huangqin. Shanxi was famous for its production of licorice in 1950s-1970s, but now it is not worth it to collect this medicinal plant in this province because of extensive digging and degradation of grasslands. The diggers of licorice have moved to other provinces to continue their digging. ${ }^{24,25}$

In upland grasslands above $1,200 \mathrm{~m}$, overgrazing is common and its influence on grassland degradation is obvious. Grassland farming in Shanxi mainly uses natural grasslands. The farmers wantonly increase the number of livestock regardless of the carrying capacity of grasslands. Excessive grazing may result in 3-5-fold decreases in grassland productivity. Soil structure is destroyed because of heavy trampling by animals, which will cause plagues of rats and insects. ${ }^{22}$ Some grasslands cannot be used for grazing any more. In addition, the development of industry and urbanization are also factors affecting grassland distribution area and degradation. ${ }^{8}$

The excessive cutting of plants is another cause leading to grassland degradation. Because of limitation of transportation and difficulty in obtaining fossil fuels in some mountainous areas, the local residents mainly use biological energy.

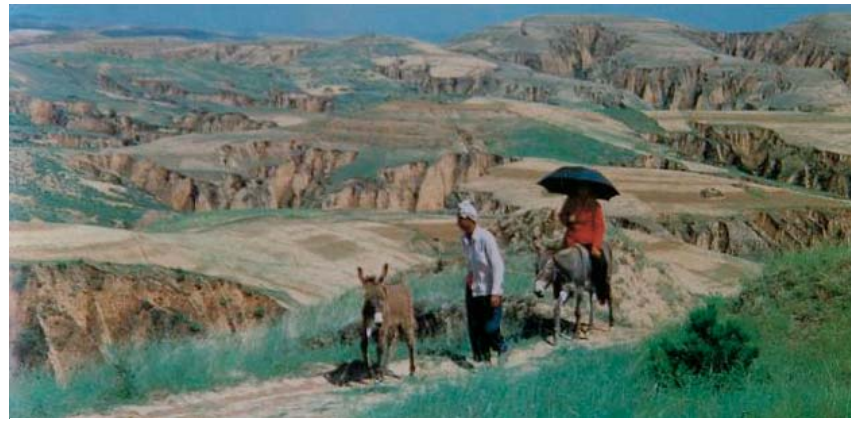

Photo 2. Seriously degraded temperate grassland in Western Shanxi. 
Mowing natural grasslands to provide winter feed for livestock is very common in mountainous areas because of the relatively long period of snow cover and the very limited area of artificial grasslands in Shanxi. These actions are detrimental to grasslands and may cause further grassland degradation.

Aside from human activities, some natural factors cannot be ignored in their role in grassland degradation in Shanxi. Frequent droughts, global warming, strong winds, uneven precipitation, and other factors all affect grassland degradation. ${ }^{26}$ According to the climate records of the past 40 years, the change of annual precipitation in Shanxi is great, with a ratio of $46 \%-95 \%$ change between years. The precipitation in a rich year is 2.6-3.5 times of that in a poor year. In the years of drought, wind and dust storms, hailstones, plagues of rats and insects become frequent, which may quicken grassland degradation. ${ }^{27}$

\section{Grassland Degradation in Shanxi}

Grasslands are principally distributed in mountains and hills in Shanxi Province. The classification of grasslands in Shanxi has been carried out many times by using different standards. ${ }^{15,23}$ The vegetation classification standards are the most common regulations used in grassland classification, ${ }^{17}$ ie, the constructive species, dominant species, and compositions of plant communities are the major principles for grassland classification in Shanxi. Based on remote-sensing image data of 2000 and a field survey in 2001, 7 types of grassland can be identified according to the criteria above (Table 1).

Shanxi is one of the provinces most seriously affected by grassland degradation in north China. ${ }^{21}$ Over $95 \%$ of grasslands in this province have been degraded to some extent. ${ }^{2}$ By using the degradation classification system summarized in Table 2, the area and percentage of degraded grasslands for each type of grassland in Shanxi are listed in Table 3. Some examples of degraded grasslands in Shanxi province are shown in Photos 1-3.

\section{Strategies of Controlling Grassland Degradation}

From the analysis above, we can see that Shanxi's grasslands are under unsustainable utilization. Degradation of grassland is continuing and worsening. Additionally, the demand for livestock industry development is imminent because of the increasing population and desired improvement of quality of life. Local government has to pay more attention to grassland-based economics, with a focus on protecting natural grassland and recovering degraded grassland, to meet the requirement of sustainable development. We put forward the following suggestions:

1) Establish a capital value system for grassland. Because the possession of grasslands belongs to the government and the access rights to grassland are not clearly established, grassland has no perceived value in China. This is one cause of grassland degradation. We should treat grassland as an important asset, and get reimbursement and invest-

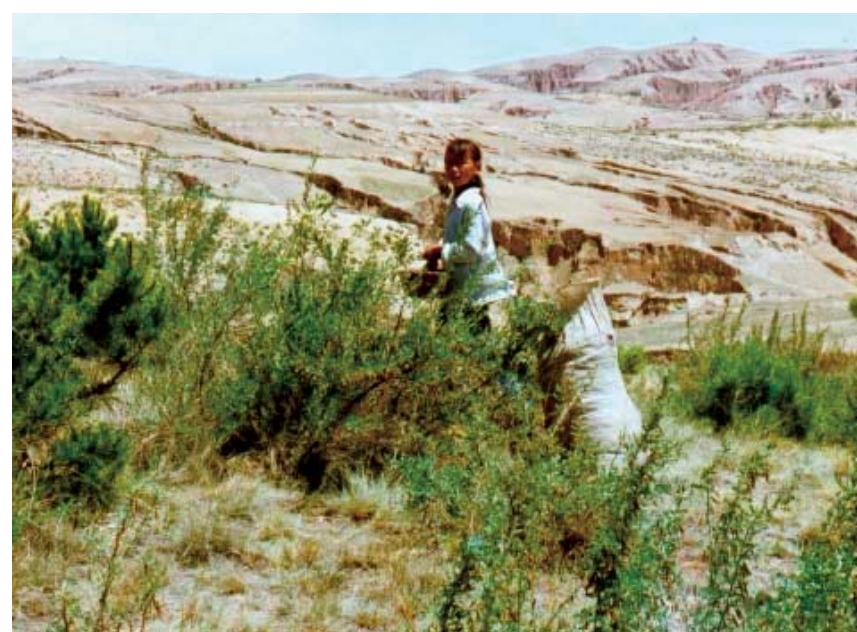

Photo 3. Extremely degraded temperate scrub-grassland in Northwest Shanxi.

ment from its utilization and for its use, restoration, and protection. It is urgent to establish a capital value system for grasslands, and to implement a series of policies to determine the accessibility of grasslands.

2) Harness and restore degraded grasslands and reconstruct pastoral grasslands. The number of livestock has exceeded the carrying capacity of grasslands in Shanxi because of large-scale degradation. If the husbandry industry needs further development, grassland area and yield will first have to increase. There are 2 ways to solve this problem. One is to harness and recover the degraded grasslands and improve their ecological situation by increasing yields. The other is to develop pastoral grasslands. There are many successful examples in practice; in one case, great ecological and economic benefits have been obtained from restoring natural grasslands and developing planted grasslands as part of the management of small watersheds of the Wangjiagou Valley in western Shanxi. ${ }^{27}$

3) Manage grasslands legally. The management of grasslands has to comply with The Law of Grasslands, The Law of Environmental Protection, and The Law of Natural Conservation to protect grasslands from such unsustainable utilizations as reclaiming, denudation, overharvesting, and excessive grazing, and enforce punishment for illegal activities. In mountainous regions with large contiguous grasslands, national parks or natural reserves should be developed to meet the needs of biodiversity conservation, ecological traveling, and scientific research.

4) Control population in mountain regions. Overpopulation is one key reason for grassland degradation; populations are too large, with high rates of increase in mountainous and poor regions in Shanxi. The pressures of population on grasslands and other natural environments are so great that ecological damage is serious. Controlling population is urgent if the natural environment is to be conserved in these regions.

5) Strengthen grasslands research and training programs. There are many theoretical and practical problems that 


\begin{tabular}{|c|c|c|c|c|c|c|}
\hline $\begin{array}{c}\text { Degradation } \\
\text { class }\end{array}$ & $\begin{array}{l}\text { Species } \\
\text { composition }\end{array}$ & $\begin{array}{c}\text { Biomass and } \\
\text { cover above } \\
\text { ground }\end{array}$ & $\begin{array}{c}\text { Surface } \\
\text { coverage and } \\
\text { situation }\end{array}$ & Soil status & $\begin{array}{c}\text { Ecosystem } \\
\text { structure }\end{array}$ & Resilience \\
\hline $\begin{array}{l}\text { I. Weak } \\
\text { degradation }\end{array}$ & $\begin{array}{l}\text { no change of orig- } \\
\text { inal species com- } \\
\text { position, individual } \\
\text { number of domi- } \\
\text { nant species and } \\
\text { palatable species } \\
\text { decreased }\end{array}$ & $\begin{array}{l}<10 \% \\
\text { decreased }\end{array}$ & $\begin{array}{l}\text { good surface } \\
\text { coverage }\end{array}$ & no change & no change & $\begin{array}{l}\text { self-recov- } \\
\text { ered in natu- } \\
\text { ral conditions }\end{array}$ \\
\hline $\begin{array}{l}\text { II. Light } \\
\text { degradation }\end{array}$ & $\begin{array}{l}\text { no great change } \\
\text { of original species } \\
\text { composition, indi- } \\
\text { vidual number of } \\
\text { dominant species } \\
\text { decreased, palat- } \\
\text { able species } \\
\text { decreased or dis- } \\
\text { appeared }\end{array}$ & $\begin{array}{l}\text { 20\%-35\% } \\
\text { decreased }\end{array}$ & $\begin{array}{l}\text { surface cover- } \\
\text { age decreased }\end{array}$ & $\begin{array}{l}\text { no obvious } \\
\text { change, soil rigidity } \\
\text { increased }\end{array}$ & $\begin{array}{l}\text { no obvious } \\
\text { change }\end{array}$ & $\begin{array}{l}\text { quickly recov- } \\
\text { ered in natu- } \\
\text { ral conditions } \\
\text { after closed }\end{array}$ \\
\hline $\begin{array}{l}\text { III. Moderate } \\
\text { degradation }\end{array}$ & $\begin{array}{l}\text { constructive and } \\
\text { dominant species } \\
\text { change greatly, } \\
\text { most original } \\
\text { species still } \\
\text { remain }\end{array}$ & $\begin{array}{l}35 \%-60 \% \\
\text { decreased }\end{array}$ & $\begin{array}{l}\text { surface cover- } \\
\text { age disap- } \\
\text { peared }\end{array}$ & $\begin{array}{l}\text { 1-fold increase of } \\
\text { soil rigidity; soil } \\
\text { erosion obvious; } \\
\text { salinity increased } \\
\text { in wet areas }\end{array}$ & $\begin{array}{l}\text { carnivores } \\
\text { decreased; } \\
\text { herbivores } \\
\text { including } \\
\text { rodents } \\
\text { increased }\end{array}$ & $\begin{array}{l}\text { May recover } \\
\text { in natural } \\
\text { conditions } \\
\text { after closed }\end{array}$ \\
\hline $\begin{array}{l}\text { IV. Serious } \\
\text { degradation }\end{array}$ & $\begin{array}{l}\text { most original } \\
\text { species disap- } \\
\text { peared, composi- } \\
\text { tion simplified, } \\
\text { short and tram- } \\
\text { pling-tolerant } \\
\text { species } \\
\text { dominated }\end{array}$ & $\begin{array}{l}60 \%-85 \% \\
\text { decreased }\end{array}$ & $\begin{array}{l}\text { soil surface } \\
\text { bared }\end{array}$ & $\begin{array}{l}\text { 2-fold increase of } \\
\text { soil rigidity; soil } \\
\text { organic matter } \\
\text { decreased obvi- } \\
\text { ously; soil sand } \\
\text { increased; salty } \\
\text { patches obvious }\end{array}$ & $\begin{array}{l}\text { food chain } \\
\text { shortened; } \\
\text { ecosystem } \\
\text { structure } \\
\text { simplified }\end{array}$ & $\begin{array}{l}\text { Hard recov- } \\
\text { ery in natural } \\
\text { conditions, } \\
\text { need improv- } \\
\text { ing measures }\end{array}$ \\
\hline $\begin{array}{l}\text { V. Extreme } \\
\text { degradation }\end{array}$ & $\begin{array}{l}\text { vegetation disap- } \\
\text { peared, only some } \\
\text { weed species }\end{array}$ & $\begin{array}{l}>85 \% \\
\text { decreased }\end{array}$ & $\begin{array}{l}\text { bared land or } \\
\text { salty patch }\end{array}$ & no value to its use & $\begin{array}{l}\text { ecosystem } \\
\text { disorganized }\end{array}$ & $\begin{array}{l}\text { Need recon- } \\
\text { struction }\end{array}$ \\
\hline
\end{tabular}

need to be solved to control grassland degradation. Research programs studying mechanisms of degradation, identifying main factors affecting degradation, and controlling degradation should be established. ${ }^{7}$ Scientific management of grasslands based on these research programs may result. It is necessary to have many technicians, managers, and teachers working to control grassland degradation and management. We should start training programs to train technical persons and educate farmers, who will be important in future efforts to recover, harness, conserve, and manage grasslands. 
Table 3. Statistics of degradation for each type of grassland in Shanxi Plateau

\begin{tabular}{|c|c|c|c|c|c|c|c|c|c|c|c|c|c|}
\hline \multirow{3}{*}{ Types } & \multirow{3}{*}{$\begin{array}{l}\text { Areas } \\
\left(10^{4} \mathrm{ha}\right)\end{array}$} & \multicolumn{12}{|c|}{ Degradation classes and areas $\left(10^{4} \mathrm{ha}\right)$} \\
\hline & & \multicolumn{2}{|c|}{ No degraded } & \multicolumn{2}{|c|}{$\mathbf{I}$} & \multicolumn{2}{|c|}{ II } & \multicolumn{2}{|c|}{ III } & \multicolumn{2}{|c|}{ IV } & \multicolumn{2}{|c|}{$\mathbf{V}$} \\
\hline & & Area & $\%$ & Area & $\%$ & Area & $\%$ & Area & $\%$ & Area & $\%$ & Area & $\%$ \\
\hline 1 & 44.0 & 0 & 0 & 0 & 0 & 5.1 & 11.6 & 8.6 & 19.6 & 17.2 & 39.1 & 13.1 & 29.8 \\
\hline 2 & 140.1 & 2.8 & 2.0 & 4.4 & 4.0 & 41.5 & 29.7 & 56.7 & 40.5 & 29.3 & 21.0 & 5.4 & 3.9 \\
\hline 3 & 60.51 & 0 & 0 & 3.6 & 6.0 & 8.1 & 13.4 & 28.7 & 47.5 & 18.9 & 31.3 & 1.21 & 2.0 \\
\hline 4 & 80.0 & 2.1 & 2.7 & 6.3 & 7.9 & 26.5 & 33.2 & 27.4 & 34.3 & 16.5 & 20.7 & 1.2 & 1.5 \\
\hline 5 & 37.0 & 6.0 & 16.3 & 8.6 & 23.3 & 15.8 & 42.7 & 6.1 & 16.5 & 0.5 & 1.4 & 0 & 0 \\
\hline 6 & 11.44 & 1.7 & 14.9 & 3.9 & 34.1 & 4.1 & 35.9 & 1.1 & 9.7 & 0.64 & 5.6 & 0 & 0 \\
\hline 7 & 3.34 & 0.6 & 18.0 & 0.8 & 24.6 & 0.9 & 27.0 & 0.54 & 16.2 & 0.3 & 9.0 & 0.2 & 6.0 \\
\hline
\end{tabular}

Note: Grassland types same as in Table 1.

6) Constitute favorable policies for grassland industries and intensive management. The current government investment in the grassland and husbandry industries is small, and farmers themselves have little capital. Therefore, the mismanagement and overutilization of grasslands are only continuing. Shanxi should constitute favorable policies to attract capital investment to grassland farming and industry, which would be conducive to sustainable development of Shanxi's economy and environment.

\section{Summary}

The present utilization and management practices of grassland farming in China, as the above case of Shanxi Province illustrates, are unsustainable. They do not accommodate the requirements of future development. ${ }^{8,13}$ The sustainable development of grassland farming refers to the enlarging of resource potential and the increased carrying capacity of grassland, which demands the improvement of grassland quality and primary production. ${ }^{3,23}$ The restoration of degraded grassland is critical for realization of sustainable grassland farming in China. Like the management of any natural ecosystem, grassland management is also important to keep natural environments stable. Therefore, sustainable grassland farming is a part of a larger process of environmental sustainable development. ${ }^{2,19,28}$

Author is Professor, College of Life Sciences, Beijing Normal University, Beijing 100875, China, zhangjintun@yahoo.com.cn. The study was financially supported by Natural Science Foundation of China (30070140) and the Teacher's Foundation of the Education Ministry.

\section{References}

1. White, R., S. Murray, And M. Rohweder. 2000. The pilot analysis of global ecosystems: Grassland systems. New York, NY: World Resources Institute. 100 p.

2. Zhang, J.-T., AND J. H. LIANG. 2001. The analysis of economic loss of ecological destruction in Shanxi, North China. (In Chinese with an English summary). China Softscience, 16(5):89-94.

3. KePE, T., And I. Scoones. 1999. Creating grasslands: social institutions and environmental change in Mkambati area, South Africa. Human Ecology 27(1):29-53.

4. World Resources Institute. 2000. World resources 2000-2001. People and ecosystems: the fraying web of life. New York, NY: WRI, UNDP, UNEP, and WB. 400 p.

5. Tracy, B. F., And M. SAnderson. 2000. Patterns of plant species richness in pasture lands of the northeast United States. Plant Ecology 149(2):169-180.

6. Bayliss, J., A. Helyar, J. T. Lee, and C. Thompson. 2003. A multi-criteria targeting approach to neutral grassland conservation. Journal of Environmental Management 67:145-160.

7. REN, J. Z. [ed]. 1998. The scientific methods of grassland research. Beijing, China: China Agriculture Press. 301 p. [In Chinese.]

8. LI, B. 1999. The paper collections of Li Bo. Beijing, China: Science Press. 450 p. [In Chinese.]

9. Burnside, N. G., R. F. SMith, And S. Waite. 2001. Habitat suitability modeling for calcareous grassland restoration in the South Downs, United Kingdom. Journal of Environmental Management 65:209-221.

10. James, L. F., J. A. Young, And K. Sanders. 2003. A new approach to monitoring rangelands. Arid Land Research and Management 17(4):364-368. 
11. Chen, Z. Z. 1988. The degradation of natural grassland and its controlling in China. In: Li, B. [ed.]. Study on control of land degradation in China. Beijing, China: China Science and Technology Press. 160 p.

12. Hong, F., AND J. Z. Ren. 2001. Welcome address. International Conference on Grassland Science and Industry; 17-20 July 2001; Hailar City, Inner Mongolia, China.

13. ZHANG, J.-T. 2002. A study on relations of vegetation, climate and soils in Shanxi Province, China. Plant Ecology 162(1):23-31.

14. MiLLER, D. 2001. Looking back to move ahead: integrating indigenous nomadic knowledge into the modern range profession in China. SRM Annual Meeting; Session on Rangeland Professionals and Society: Future Directions; 20 February 2001; Kailua-Kona, HI.

15. ZHANG, J-T. 1989. The types of grassland resources and their mathematical evaluation and rational utilization in Shanxi. Journal of Shanxi University (Natural Science Edition) 12(1):95-103. [In Chinese with an English summary.]

16. JiN, J. M. 1991. An introduction to natural protection. Beijing, China: Environmental Science Press. [In Chinese.]

17. Wu, Z. Y. [ed.]. 1982. Vegetation of China. Beijing, China: Science Press. 800 p. [In Chinese.]

18. LiU, Z. Y. [ed.]. 1992. Soils in Shanxi Province. Beijing, China: Science Press. 456 p. [In Chinese.]

19. Huebner, C. D., J. L. Vankat, and W. H. Renwick. 1999. Change in the vegetation mosaic of central Arizona USA between 1940 and 1989. Plant Ecology 144(1):83-91.
20. Weltz, M. A., G. Dunn, J. Reeder, And G. Frasier. 2003. Ecological sustainability of rangelands. Arid Land Research and Management 17(4):369-388.

21. JiAnG, S. 1988. Grassland degradation and its controlling strategies. Natural Resources (3):54-61. [In Chinese with an English summary.]

22. WANG, Y. F. 1991. Vegetation resources and their utilization and protection in Loess Plateau. Beijing, China: China Science and Technology Press. 371 p. [In Chinese.]

23. ZHENG, F. Y., AND J.-T. ZHANG. 1996. Grassland resources and their rational utilization in Shanxi. Mountain Research 14(1):33-38. [In Chinese with an English summary.]

24. ZHANG, J.-T. 1987. The main vegetation types and their rational utilization in Northwest Shanxi. Journal of Wuban Botanical Research, 5:373-382. [In Chinese with an English summary.]

25. Editing Group of Shanxi Land Resources. 1995. Generality of Shanxi land resources. Beijing, China: China Environmental Press. 456 p. [In Chinese.]

26. ZHANG, X. S. 1993. The vegetation-climate classification system for study on global change. Study on the Quaternary Period 2(3):157-169. [In Chinese with an English summary.]

27. ZHANG, J.-T. 2000. The relationship between environmental decline and the destruction of vegetation in Loess Plateau. Journal of Shanxi University (Natural Science Edition) 23(Suppl.):37-41.

28. ZHANG, J.-T. 1999. Agroforestry and its practice in Loess Plateau, China. Henan Science 17(Suppl.):80-82. [In Chinese with an English summary.] 